(c) Ryabykh S.O., Savin D.M., Sayfutdinov M.S., Ochirova P.V., Gubin A.V., Filatov E.Yu., Ulrikh G.E., Skrypnikov A.A., 2019

DOI 10.18019/1028-4427-2019-25-4-550-554

\title{
Surgical treatment of Sprengel's deformity using neurophysiological monitoring: analysis of a 7-year cohort
}

\author{
S.O. Ryabykh¹, D.M. Savin ${ }^{1}$, M.S. Sayfutdinov ${ }^{1}$, P.V. Ochirova ${ }^{1}$, A.V. Gubin ${ }^{1}$, E.Yu. Filatov ${ }^{1}$, \\ G.E. Ulrikh ${ }^{2}$, A.A. Skrypnikov ${ }^{1}$
}

${ }^{1}$ Russian Ilizarov Scientific Center for Restorative Traumatology and Orthopaedics, Kurgan, Russian Federation,

${ }^{2}$ Saint-Petersburg State Pediatric Medical University, Saint-Petersburg, Russian Federation

\begin{abstract}
Design Presentation of clinical cases and literature analysis. Material and methods Clinical observation of patients with congenital cervical spine and shoulder girdle anomalies operated on with neuromonitoring was performed. Operative treatment of Sprengel's deformity was produced with the use of neuroimaging. Results Surgical treatment resulted in good clinical outcomes without neurological adverse events and good aesthetic and radiological appearance at the descended scapula. Discussion Consideration for intraoperative neuromonitoring should be given to prevent neurological complications at lowering the elevated scapula. Conclusion Review of outcomes showed efficacious application of the most valid methods used to descend the scapula with neuromonitoring. This was supported by clinical and radiological findings of the extent of cranial transposition after appropriate correction and absence of neurological adverse events early postsurgery and at a longterm follow-up. No recurrence of scapular dislocation was observed at a long-term follow-up.
\end{abstract}

Keywords: Sprengel's deformity, elevation of the scapula, neuromonitoring, electroneuromyography

\section{INTRODUCTION}

Sprengel's shoulder or congenital elevation of the scapula is an abnormality of the shoulder girdle [1]. Surgical treatment is performed to improve cosmetic appearance by transferring the scapula down and fixing it to the physiological bed [2]. There are approximately 30 surgical techniques [3] developed and introduced to correct scapular anatomical position. However, the risk of complications is reported to range from $12.5 \%$ to $58.7 \%$ with paresis of the upper limb due to a brachial plexus injury being the most severe complication of shoulder dislocation [4].

Objective: to improve outcomes of surgical treatment of patients with Sprengel shoulder.

Design: retrospective cohort study.

Level of evidence: 4 (UK Oxford, version 2009).

\section{MATERIAL AND METHODS}

The study included 18 patients with Sprengel shoulder treated at the clinic of spine pathologies and rare diseases of the Russian Ilizarov Scientific Center "Restorative Traumatology and Orthopaedics“ between 2014 and 2018. The patients' age ranged from 2 years 5 months to 14 years with the mean age of 7.0 years. There were 15 girls and 3 boys. 9 patients had elevation of the right scapula and 8 had elevation of the left scapula. Omovertebral bone was detected in two cases. One child had bilateral involvement.

Thedisease coexisted with congenital abnormalities of the spine and chest wall (malsegmentation of the cervical spine (Klippel-Feil syndrome), of the thoracic spine, agenesis, costal concrescence) in all cases.
Methods of study used included physical examination, imaging (biplane radiographic telemetry of spine, CT of the chest wall, thoracic spine and shoulder girdle), functional methods (electroneuromyography (ENMG) of upper limbs, intraoperative neurophysiological monitoring (IONM) and SRS-24 patient questionnaire. Descriptive statistics was employed due to a small patient cohort.

Pre- and postoperative evaluation criteria:

- clinical assessment of scapular positioning according to the Cavendish grading system;

- radiological evaluation of cranial displacement according to the Rigault grading system identifying

(1) Ryabykh S.O., Savin D.M., Sayfutdinov M.S., Ochirova P.V., Gubin A.V., Filatov E.Yu., Ulrikh G.E., Skrypnikov A.A. Surgical treatment of Sprengel's deformity using neurophysiological monitoring: analysis of a 7-year cohort. Genij Ortopedii, 2019, vol. 25, no 4, pp. 550-554. DOI 10.18019/1028-4427-2019-25-4-550-554. (In Russian) 
scapular rotation, ${ }^{\circ}$; hypoplasia, cm; shoulder balance, $\mathrm{cm}$ (radiometric measurements were produced with Surgimap Spine software);

- shoulder abduction;

- presence of abnormal asymmetric vertebrae;

- «mean range» of resultant ENMG;

- dynamics in baseline MEPs measured intraoperatively using IONM.

Minimal and maximal follow-up periods were 8 and 48 months, respectively, with the mean follow-up period of 28 months.

\section{Surgical technique}

The Woodward technique [5] was employed to bring the scapula inferiorly to its normal level using IONM in all cases. A linear incision from the spinous process of the fourth cervical vertabra to that of the ninth thoracic vertebra was made undermining the skin and soft tissues and exposing the medial, superior and inferior borders of the scapula. Then $m$. levator scapulae, $m$. trapezius and fibrous bands attached to the scapula were incised. As opposed to Green's scapula procedure [6], m. latissimus dorsi and $m$. trapezius were detached $2-3 \mathrm{~cm}$ off the medial border of the scapula but not exactly on the medial border. Any omovertebral bone or fibrous band were excised. The scapula was mobilized, rotated in coronal plane and moved caudad to a more normal position due to transposition of $m$. latissimus dorsi and $m$. trapezius. Contralateral scapula was used for identifying adequate scapuloplasty except for bilateral cases. Inferior scapular angle was trasported down to the $7^{\text {th }}-8^{\text {th }}$ intercostal space. The scapula was fixed and sutured into the pockets in the above muscles using non-resorbing threads.

The clavicle was osteotomized on the ipsilateral side in 5 cases to improve mobilization of the shoulder girdle and avoid brachial plexus palsy. Spine deformity correction and local transpedicular fixation were produced for four patients with segmental instability secondary to block vertebrae nonsegmentation (Fig. 1) [7, 8].

\section{Protocol of intraoperative neurophysiological} monitoring

IONM was used to prevent iatrogenic injury to the brachial plexus and the development of postoperative neurological deficit. ISIS neuromonitoring system (Inomed Medizintechnik GmbH, Germany) was used to assess motor tract function of the major terminal branches of the brachial plexus. Transcranial electric stimulation of motor cortex was used to elicit motor evoked potentials (MEPs) with corkscrew needle electrodes placed at scalp position C3/C4 using anatomical surface landmarks according to international 10-20 EEG system. MEPs were recorded from $m$. deltoideus, $m$. biceps brachii, $m$. triceps brachii, m. extensor digitorum, mm. thenar, $\mathrm{mm}$. hypothenar with monopolar needle electrodes («belly-tendon» typed lead). Transcranial stimulation was produced with a train of stimuli each consiting of five impulses. Duration of a train of stimuli was $1 \mathrm{msec}$, inter-stimuli interval was set at $4 \mathrm{msec}$, frequency of $1 \mathrm{~Hz}$ and intensity of 80-150 MA. The most common alarm criterion was reported [9] to be a $50 \%$ drop in the signal amplitude and a more than $10 \%$ increase in latency periods.
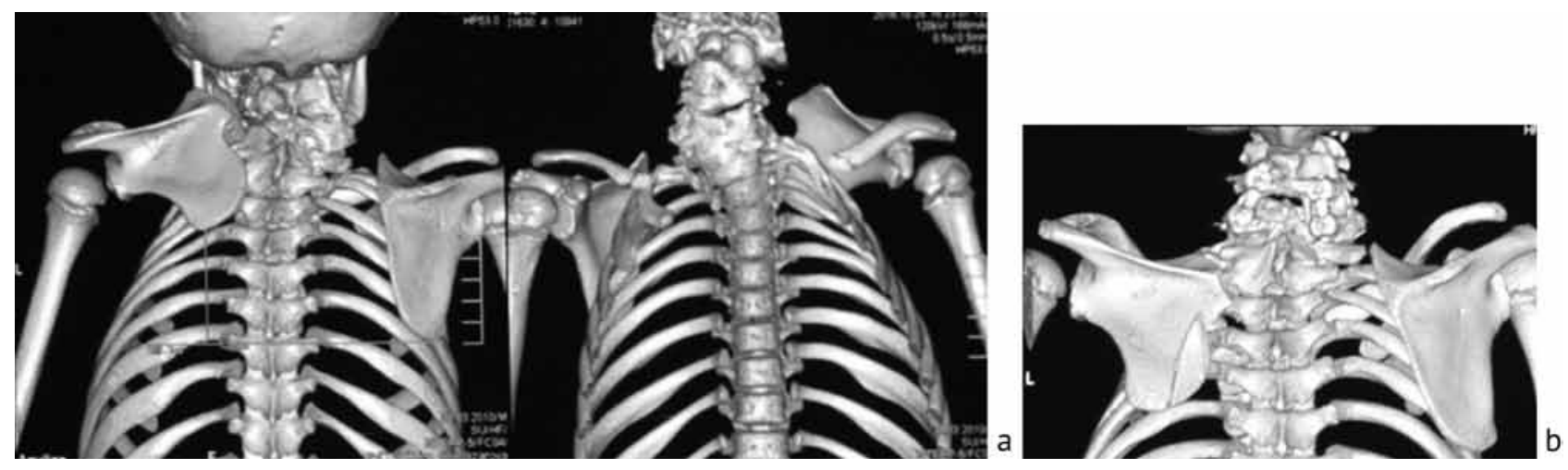

Fig. 1 3D CT scan (VRT) of a boy aged 6 years 7 months with congenital spine abnormality secondary to malsegmentation of C0-Th3 and elevation of the left scapula: (a) 3D CT scan image (VRT) in ventral view shows combined anomaly of the cervical spine and elevated left scapula; $(\boldsymbol{b})$ postoperative 3D CT scan image (VRT) in dorsal view showing Mayfield head clamp applied; correcting posterior vertebrotomy performed at the C2-C3 vertebral level (conventionally). Spinal curve was corrected with the $3.5 \mathrm{~mm}$ Synaps system. Posterior spondylodesis was produced using autologous bone graft. The Woodward procedure was performed to descend the left scapula 
Patients presented with cosmetic disturbances of the shoulder girdle and the neck and limited abduction of the upper limb. Physical examination revealed asymmetric shoulder girdle and collar zone, elevation of a scapula (added by torsion in the coronal plane in one case) and limited abduction of the upper limb up to $120^{\circ}$.

Preoperative assessment with the Cavendish classification showed asymmetry of the scapulae of 2-5 $\mathrm{cm}$ and rotation relative to the horizontal plane. Postoperative shoulder position appeared to be normal with good clinical ratio and symmetry achieved between superior medial and inferior scapular angles $(\mathrm{n}=16 ; 88.9 \%)$. Persistent asymmetry of the superior medial scapular angles was noted without clinically evident asymmetry of the shoulder girdle $(n=2$; $11.1 \%$ ) (Table 1, Fig. 2).

Table 1

Clinical evaluation of cranial displacement using the Cavendish classification [10]

\begin{tabular}{|l|c|c|}
\hline Cavendish grade & Preoperatively & Postoperatively \\
\hline Grade I & 1 & 16 \\
\hline Grade II & 10 & 2 \\
\hline Grade III & 6 & 0 \\
\hline Grade IV & 1 & 0 \\
\hline
\end{tabular}
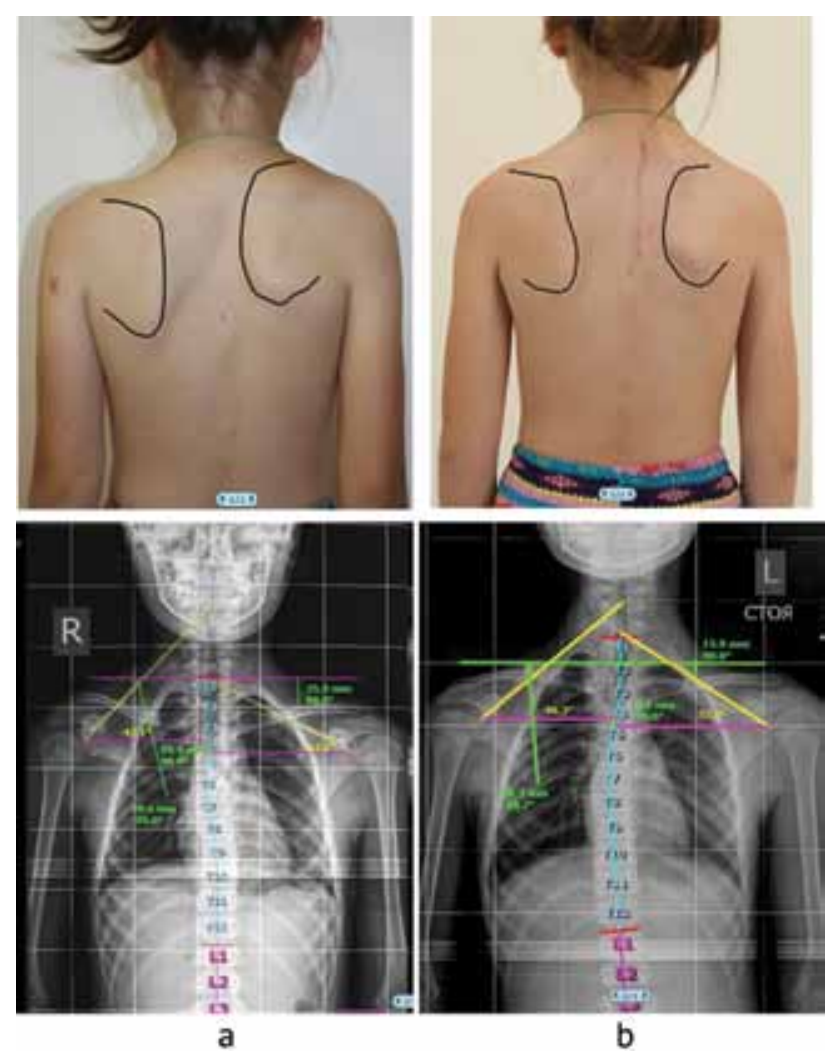

Fig. 2 Preoperative photograph and radiographs of a 9-year-old patient with Sprengel shoulder (the right scapula was brought inferiorly using the Woodward procedure added by osteotomy of the right clavicle) $(\boldsymbol{a})$ and at 2-year follow-up (b)
Radiological evaluation of cranial scapular displacement showed the superior medial scapular angle at the C5-Th3 level preoperatively and at the Th2-Th4 level postoperatively.

Table 2

Radiological evaluation of cranial scapular displacement using the Rigault classification [11]

\begin{tabular}{|l|c|c|}
\hline Тип по Rigault P. & Preoperatively & Postoperatively \\
\hline Grade I & 8 & 18 \\
\hline Grade II & 9 & 0 \\
\hline Grade III & 1 & 0 \\
\hline
\end{tabular}

ENMG examined an average amplitude at the maximal voluntary contraction and showed moderate decrease in function of the bilateral upper limb muscles (8 major muscles of the shoulder) that measured $55.9 \pm 2.7 \%$ in one case and $50.8 \pm 3.6 \%$ in another case, with no damage to the spinal cord motor pathways. With the access to the surgical site accomplished and the muscle relaxant effect (used for anesthetic induction) complete baseline MEPs representing polyphase responses of different amplitude (up to $3 \mathrm{mV}$ ) and latency of about $20 \mathrm{msec}$ were obtained. Intermittent neuromonitoring of upper extremity was intraoperatively produced for the patients. Current MEP characteristics were compared with baseline potentials. No negative changes in the MEP charactreistics were intraoperatively detected in both cases that indicated to the absence of aggressive effect on motor pathways in the proximity to surgical manipulations (Fig. 3). No neurological deficit of the upper limb was observed postsurgery.
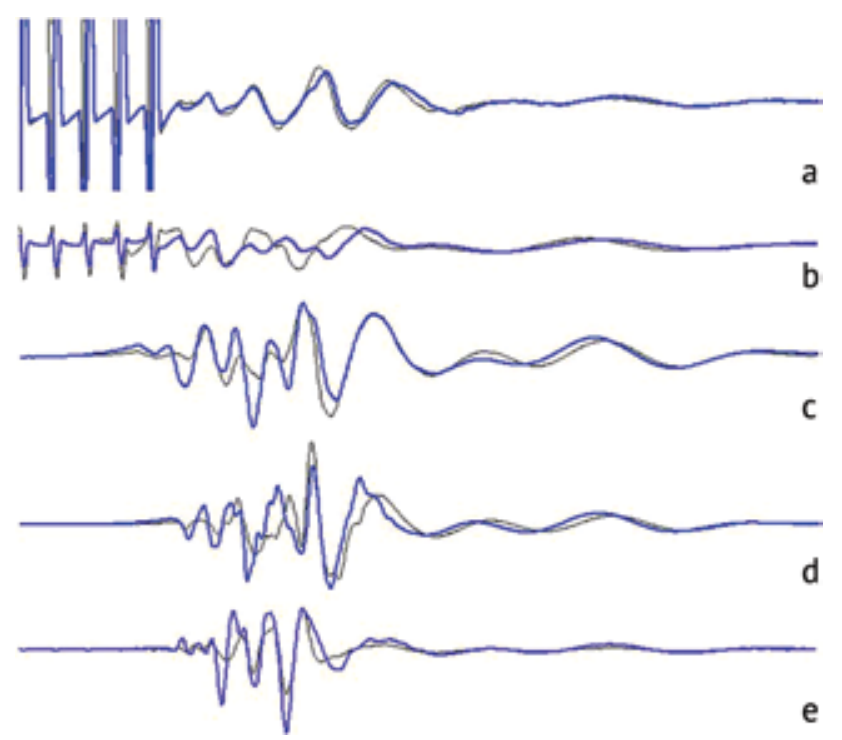

Fig. 3 Transcranially elicited evoked motor responses of muscles of the upper limb in a 9-year-old patient with Sprengel shoulder on the right $(\boldsymbol{a}-m$. deltoid. ac., $\boldsymbol{b}-m$. biceps br., $\boldsymbol{c}-m$. extensor dig., $\boldsymbol{d}-m m$. thenar, $\boldsymbol{e}-m m$. hypothenar). Violet-colored line - baseline MEP, fine line - MEP in response to the current test signal 


\section{DISCUSSION}

Leibovic S.J. et al. [12] reviewed 18 patients in their original study and reported improvement in cosmetic appearance in all cases, however, the outcomes showed limited shoulder abduction ranging from 148 to $91^{\circ}$. No neurological complications were noted. Several patients developed partial recurrence at a two-year follow-up and reoperation was performed for two patients.

Andrault G. et al. [13] reviewed outcomes of eight children at a mean follow-up of $41 / 2$ years. Cosmetic appearnce improved in all patients and parents were satisfied with the outcomes.

Agarwal A. et al. [14] employed vertical scapular osteotomy for treatment of 8 patients and the procedure was associated with satisfactory results due to the presence of rib anomalies affecting postoperative outcomes. The patients increased shoulder abduction by $21^{\circ}$. The group with minor rib anomalies or none costal pathologies showed $28^{\circ}$ increase in shoulder abduction and complicated costal conditions resulted in $10^{\circ}$ improvement. No neurological complications were reported.

The risk of brachial plexopathy [4] at the side of operative intervention is directly related to the extent of the scapular descent. The integrity of neural pathways directly monitored intraoperatively is vital in predicting true neurological compromise $[15,16]$. IONM is an invaluable tool for assessing neurological status and improving safety facilitating mobilization and trasposition of the scapula to the level wanted with minimal risk of neurological complications.

\section{CONCLUSION}

Review of outcomes showed efficacious application of the most valid methods used to descend the scapula with neuromonitoring. This was supported by clinical and radiological findings of the extent of cranial transposition after appropriate correction and absence of neurological adverse events early postsurgery and at a long-term follow-up. No recurrence of scapular dislocation was observed at a long-term follow-up.

Comments It should be noted that high interrater agreement was ensured between all operating surgeons (4 authors: 1, 2, 4, 5) regarding more comfortable and controllable performance of surgical procedure of scapular descent. This is beyond the scope of the article and requires further multicenter study.

Limitations A small cohort of patients, monocenter study, medical history of at least 48 months. The findings can be interpreted as an intermediate insight and the study needs further recruitment and clinical analysis.

\section{REFERENCES}

1. Kolchin D.V. Ranniaia diagnostika vrozhdennogo vysokogo stoianiia lopatki [Early diagnosis of congenital high scapula]. Khirurgiia Pozvonochnika, 2009, no. 1, pp. 69-75. (in Russian)

2. Zhila N.G. Khirurgicheskoe modelirovanie pravilnoi formy grudnoi kletki u detei i podrostkov pri vrozhdennykh i priobretennykh deformatsiiakh [Surgical modelling proper chest shape in children and adolescents with congenital and acquired deformities]. Khabarovsk, Izd-vo DVGMU, 2002, 223 p. (in Russian)

3. Pozdeev A.A. Operativnoe lechenie tiazhelykh form vrozhdennogo vysokogo stoianiia lopatki u detei [Surgical treatment of severe shapes of congenital high scapula in children]. Vestnik Khirurgii im. I.I. Grekova, 2006, vol. 165, no. 1, pp. 56-61. (in Russian)

4. Fishchenko P.Ia. Vrozhdennoe vysokoe stoianie lopatki [Congenital high scapula]. Almanakh Klinicheskoi Meditsiny, 2005, no. 8-1, pp. 351-355. (in Russian)

5. Woodward J.W. Congenital elevation of the scapula correction by release and transplantation of muscle origins. A preliminary report. J. Bone Joint Surg. Am., 1961, vol. 43, pp. 219-228.

6. Green W.T. The surgical correction of congenital elevation of the scapula (Sprengel's deformity). J. Bone Joint Surg. Am., 1957, vol. 39A, pp. 1439-1448.

7. Riabykh S.O., Savin D.M., Filatov E.Iu. Klinicheskii sluchai operativnogo lecheniia tiazhelogo vrozhdennogo kifoskolioza u rebenka 11 let [A clinical case of surgical treatment of severe congenital kyphoscoliosis in an 11-year old child]. Genij Ortopedii, 2017, vol. 23, no. 2, pp. 216-219. (in Russian) DOI: 10.18019/1028-4427-2017-23-2-216-219.

8. Riabykh S.O., Filatov E.Iu., Savin D.M. Trekhkolonnye vertebrotomii vne apikalnoi zony kak sposob korrektsii deformatsii sheinogrudnogo perekhoda: analiz klinicheskoi serii i dannykh literatury [Three-column vertebrotomies outside the apical zone as a way to correct deformities of the cervicothoracic transition: analysis of the clinical series and data of the literature]. Khirurgiia Pozvonochnika, 2017, vol. 14, no. 3, pp. 15-22. (in Russian) DOI: 10.14531/ss2017.3.15-22.

9. Saifutdinov M.S., SkripnikovA.A., Savin D.M., Ochirova P.V., Tretiakova A.N. Metodicheskie problemy razvitiia intraoperatsionnogo neiromonitoringa pri operativnoi korrektsii deformatsii pozvonochnika (obzor literatury) [Methodological problems of intraoperative 
neuromonitoring during operative correction of spinal deformity (literature review)]. Genij Ortjpedii, 2017, vol. 23, no. 1, pp. 102110. (in Russian) DOI: 10.18019/1028-4427-2017-23-1-102-110.

10.Cavendish M.E. Congenital elevation of the scapula. J. Bone Joint Surg. Br., 1972, vol. 54, no. 3, pp. 395-408.

11.Rigault P., Puoliquen J.C., Guyonvarch G., Zujovic J. Congenital elevation of the scapula in children. Anatomo-pathological and therapeutic study apropos of 27 cases. Rev. Chir. Orthop. Reparatrice Appar. Mot., 1976, vol. 62, no. 1, pp. 5-26.

12.Leibovic S.J., Ehrlich M.G., Zaleske D.J. Sprengel deformity. J. Bone Joint Surg. Am., 1990, vol. 72, no. 2, pp. $192-197$.

13.Andrault G., Salmeron F., Laville J.M. Green's surgical procedure in Sprengel's deformity: cosmetic and functional results. Orthop. Traumatol. Surg. Res., 2009, vol. 95, no. 5, pp. 330-335. DOI: 10.1016/j.otsr.2009.04.015.

14.Agarwal A., Arkesh M., Jandial G. Sprengel's deformity correction by vertical scapular osteotomy in a paediatric age group: influence of rib cage abnormalities. Int. Orthop., 2018, vol. 42, no. 9, pp. 2191-2197. DOI: 10.1007/s00264-018-3887-x.

15.Shein A.P., Krivoruchko G.A., Riabykh S.O. Reaktivnost i rezistentnost spinno-mozgovykh struktur pri vypolnenii instrumentalnoi korrektsii deformatsii pozvonochnika [Reactivity and resistance of cerebrospinal structures when performing instrumental correction of the spine deformities]. Rossiiskii Fiziologicheskii Zhurnal im. I.M. Sechenova, 2016, vol. 102, no. 12, pp. 1495-1504. (in Russian)

16.Saifutdinov M.S., Riabykh S.O. Neirofiziologicheskii kontrol funktsionalnogo sostoianiia piramidnoi sistemy v protsesse lecheniia bolnykh s deformatsiei pozvonochnika [Neurophysiological control of the pyramidal system functional condition in the process of treating patients with the spine deformity]. Nevrologicheskii Zhurnal, 2018, vol. 23, no. 5, pp. 248-258. (in Russian)

Received: 29.07.2019

\section{Information about the authors:}

1. Sergey O. Ryabykh, M.D., Ph.D., Russian Ilizarov Scientific Center for Restorative Traumatology and Orthopaedics, Kurgan, Russian Federation, Email: rso_@mail.ru

2.Dmitry M. Savin, M.D., Ph.D., Russian Ilizarov Scientific Center for Restorative Traumatology and Orthopaedics, Kurgan, Russian Federation

3. Marat S. Sayfutdinov, Ph.D. of Biological Sci.,

Russian Ilizarov Scientific Center for Restorative Traumatology and Orthopaedics, Kurgan, Russian Federation

4.Polina V. Ochirova, M.D., Ph.D.,

Russian Ilizarov Scientific Center for Restorative Traumatology and Orthopaedics, Kurgan, Russian Federation

5. Alexander V. Gubin, M.D., Ph.D.,

Russian Ilizarov Scientific Center for Restorative Traumatology and Orthopaedics, Kurgan, Russian Federation, Email: shugu19@gubin.spb.ru

6. Egor Yu. Filatov, M.D.,

Russian Ilizarov Scientific Center for Restorative Traumatology and Orthopaedics, Kurgan, Russian Federation

7. Gleb E. Ulrikh, M.D., Ph.D., Professor,

Saint-Petersburg State Pediatric Medical University, Saint-Petersburg, Russian Federation,

Email: gleb.ulrikh@yandex.ru

8. Alexander A. Skripnikov, M.D., Ph.D.,

Russian Ilizarov Scientific Center for Restorative Traumatology and Orthopaedics, Kurgan, Russian Federation, Email: skripnikov2007@mail.ru 